\title{
The Origins of the Communist Rule in Eastern Europe:
}

\author{
A Brief History
}

\author{
Azlizan Mat Enh
}

\begin{abstract}
The history of communist rule is long and varied. Communism as a ruling system emphasizes on economy and balanced distribution of wealth and ownership of property among all the people. This system originated from the ideology of Karl Marx in 1845. Communist system in Eastern Europe was fostered by Soviet Union after the fall of Nazism at the end of World War II. This paper focuses on how the Eastern European states fell under the influence of Communist after World War II. It discusses how salami tactics were used by Soviet Union as one the methods to establish communist government in Eastern Europe. It also shows that Soviet Union's position as a super power in Eastern Europe enabled her to spread communist ideology in the region.
\end{abstract}

Keywords: Communist, Eastern Europe, America, Soviet Union, Salami Tactics.

\section{Introduction}

States in Eastern Europe gradually fell into the hands of Soviet Union after World War II. Communism has a ruling system emphasizes on economy and balanced distribution of wealth among all people. This system originated from the ideology of Karl Marx in 1845. The Communist system in Eastern Europe was fostered by the Soviet Union. The collapse of Nazism after World War II had caused a vacuum in the political system in Eastern Europe. The good relationship between Soviet Union and Eastern Europe since World War I enabled the Soviet Union to infiltrate communist ideology into the region. Furthermore, the Yalta Agreement of February 1945 provided contractual validity for Soviet domination in Eastern Europe and installation of Communist regimes there. United States policy and strategy to promote democracy could not be implemented in Eastern Europe ${ }^{1}$. Soviet Union had stressed that it was the right of the states in Eastern Europe to choose the government of their choice after the elimination of Nazism from the region. The Yalta Agreement had maintained that all the countries in principle were under the Soviet protection. Besides, Soviet had installed her military in all the Eastern 
European countries after the elimination of Nazism. This tactic had made it difficult for the Western powers to prevent Communist influence in Eastern Europe.

"The presence of the Soviet Army in Eastern Europe made it physically impossible for the Western Powers to prevent this. Eastern Europe was thus prevented from creating the democratic institutions of their own choice and never had the freedom to choose their own forms of government in the sense understood in Western Europe",2.

\section{Yalta Agreement}

Suggestion to Balkan spheres of 'interest' or 'influence' between Soviet and the Western Powers were for the first time discussed on May 1944 between Eden and Gusev in London. The Soviet Government apparently agreed to the proposal of the British Government that, as a practical measure, Romanian affairs would be the main concern of the Soviet Government and the Greek affairs would be the main concern of His Majesty's government. In June 1944, when Churchill and Eden visited Stalin and Malotov in Moscow, the question of spheres of interest were raised again and the percentage figures for 'preponderance' were mentioned. By this stage, the Soviet Government was using the June 1944 agreement that the British and United States governments had given them the balance in parts of the Balkans, including Rumania and Bulgaria. President Truman speech was reported in a newspaper on 10 August $1945^{3}$ which read:

".............at Yalta it was agreed, you will recall, that the three governments would assume a common responsibility in helping to re-establish in the liberated and satellite nations of Europe governments broadly representative of democratic elements in the population. That responsibility still stands. We all recognize it as a joint responsibility of the three governments.

- It was reaffirmed in the Berlin declaration on Romania, Bulgaria and Hungary. These nations are not to be spheres of influence of any one power. They now are governed by Allied control commissions composed of representatives of the three governments, which met at Yalta and Berlin. These control commissions, it is true, have not been functioning completely to our satisfaction; but improved procedures were agreed upon at Berlin. Until these states are re-established as members of the international family, they are the joint concern of all of us......"

\section{Communist Diplomacy}

In November 1941, the Soviet government declared that the European people would be allowed full liberty to choose their own political system. When the Soviet Army entered Romania in April 1944, the Soviet Union declared it was "not aiming to acquire any part of Romanian territory or change the existing social order”. In October 1944, Stalin, 
Molotov and Dimitrov (who became leader of the Bulgarian Communist Party in November 1945) assured the Bulgarian government that the Soviet Union did not wish to see a Communist regime established in Bulgaria. Dimitrov, in a speech on 6 November 1945, said,

"It is a wicked legend and calumny that the communists want to assume whole power...It is not true that the Communists want to have a one-party administration". 4

At the same time the East European Communists with the active support of the Soviet Union were planning a transition to Communism on the lines presented by Lenin in 'Two Tactics of Social-Democracy in the Democratic Revolution'.(July 1905) i.e. on the basis of an intermediate stage consisting of a 'revolutionary-democratic dictatorship of the - proletariat and the peasantry'. This dictatorship he wrote, 'must inevitably rely on

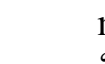
military force, on the arming of the masses... and not on institutions established in a 'lawful' or 'peaceful way'. The February 1948 coup in Czechoslovakia, carried out with the help of the Communist militia, was an example of the "arming of the masses".

(1)

The 'Two Tactics' in the title of Lenin's pamphlet referred to the question of whether or

- not Communists should participate in provisional or coalition governments at the intermediate stage. His answer was that there should, and be a 'united front' or 'popular front' tactics which have since been practiced by Communists in all parts of the world (under the guise of national liberation fronts in colonial countries). The aim was to unite parties or groups representing the workers, peasants and as many other sections of the population as possible under Communist leadership. In practice, the Communists had shown themselves ready to cooperate with virtually any other group, provided there were - good prospects that they can dominate the front and not lose their own identity as a party. Experience had shown that political and other leaders who have served in coalition governments with Communists, whether for good motives or for reasons of ambition, have usually been sacrificed as soon as they had served their purpose of helping the communists into power. Such people include S. Mikolajczyk, leader of the Peasant Party and Vice-Premier in Poland; Ferenc Nagy, leader of the Smallholder's Party and Prime Minister in Hungary; Jan Masaryk, Foreign Minister and son of the founder President of Czechoslovakia; Nikola Petkov, Secretary-General of the Agrarian Party and VicePremier in Bulgaria; and Iuliu Maniu, leader of the National Peasant Party and VicePremier in Romania.

In his 1952 lecture, 'The Road to our People's Democracy,5, Matyas Rakosi, leader of the Hungarian Communist Party, was frank about the tactics. 'We did not discuss the problem before the people at the time'. He had added, 'because even a theoretical discussion of a dictatorship of the proletariat as a final aim would have caused great alarm among our partners in coalition'. He then gave the memorable description of the work of 'unmasking' and eliminating opposition to the Communists as 'salami tactics. ${ }^{6}$

The coalition governments established in Eastern Europe after the war, in which the communists at first cooperated normally and concealed their ultimate intentions from 
their partners, generally went through two stages. In the first, the non-communist partners were systematically eliminated. Special hostility was directed at figures like Iuliu Maniu (Peasant Party) in Romania and Nikola Petkov (Agrarian Party) in Bulgaria, both had been respected anti-Nazi figures dedicated to the pursuit of social justice. After show trials, Maniu was sentenced to life imprisonment and Petkov was executed. In the second stage, the Socialist or Social Democratic Party (where it existed) merged with the Communist Party - and was emasculated by it. The supremacy of the Communist Party was then enshrined in a constitution modeled on that of the Soviet Union, and republics were set up and described as 'People's Democracies'. This is an early stage in the long process of development towards full communism. Although the communists were generally a minority in the initial coalitions, they insisted wherever possible being given - certain key posts in the government, such as the Ministry of the Interior.

The 'United Parties' were vigorously purged again to criminate any remaining uncommunicable elements. Even the leaders who performed such useful services in betraying their parties to the Communists suffered; for example, the Hungarian Justus who had been Szakasits principal assistant in enslaving Hungary's Social Democrats, was - framed and imprisoned for life in connection with the Rajk trial.

The Communist strategies were carefully noted by Socialists everywhere. They include:

1) elimination of those Socialists known to be most determined to maintain party independence, as a condition of collaboration.

2) importation of fellow- travellers by force or fraud, where possible.

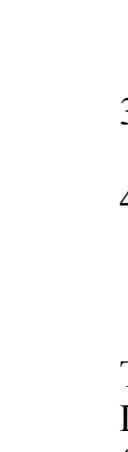

arrest and imprisonment of true Socialists- like Lulchov, Petrescu and Puzak.

4) forcible dissolution of the Socialist Party into the Communist Party when it has been sufficiently broken. The nature of this unification is well expressed by Marosan, a Hungarian crypto-Communist;

The prediction of the opponents of unity that the Communists would 'swallow' the Social Democrats because of unification was not justified. Only unification made it possible for former Social Democrats successfully to master the great weapon of Marxist-Leninist theory ${ }^{7}$ and to become free, selfless Communists. (Cominform Journal, $15^{\text {th }}$ June, 1949) ${ }^{8}$. 


\section{Eastern Europe Under Communism ${ }^{9}$}

\section{Poland}

There were no disturbing issues that had shaken the $\mathrm{PKP}^{10}$ apart from the Poland Nationalism Movement, which became an enormous influence to PKP. Prior to 1918, Poland had established a very good rapport with Russia and following this relationship, the Marxist influence was strong. The only problem during this period was the different views towards the Marxism. These had caused the Communist Workers Party of Poland, established in 1918, to split into Nationalism Party and Cosmopolitan Party. ${ }^{11}$

- Cosmopolitan Party was the strongest until 1938 because it received support from Russia. This party rejected Poland's independence as a harmful to the interests of the Polish proletariat. $^{12}$ The Nationalist Party did not agree and demanded independence from the Bolshevik-Marxist orientation and fought for the class struggle, which was more domestic, and which rejected the international flow besides distinctness of Polish socio economic conditions. Conflict of ideology between these two parties was a trend in communist movement in Poland, which brought important implication in the struggle of communist in Poland. The struggle of the Nationalist Party after World War II was supported by the proletariat and they managed to play a dominant role in Poland until 1956 when they were replaced by Cosmopolitan Party.

In Poland, the Lublin Committee composed of communists and crypto-communists was set up under Soviet auspices in July 1944 and established a government in Warsaw that excluded all representatives of the Polish Government in exile in London, which had wide popular support in Poland. The Yalta Agreement contained a special section on Poland, providing for her people to create "democratic institutions of their own choice" through "free and unfettered elections on the basis of universal suffrage and secret ballot". Following pressure from the Western Powers, the Polish Communist regime agreed in June 1945 to include representatives of some of the parties in exile in a new

- government but gradually made their position impossible. Communist Party supporters held eighteen ministries and other parties only six. The communists, who feared they would not win the promised free and unfettered elections, then began a ruthless persecution campaign against the other parties. Elections were eventually held in January 1947, but under such conditions that the Communists easily consolidated their position. At a speech at the National War College in mid 1947, William C. Bullitt, formerly from the States Department asserted that, the final aim of Soviet Union is world conquest. ${ }^{13}$ By the end of 1948, they had virtually eliminated all opposition by the use of "salami tactics" and assumed complete control of the government. For example, in the case of banks, initially they took control of the state's banks and later they nationalized three big banks. Similarly, in the industry they first demanded state management of the mines then gradually extended to the bigger machinery plans and finally nationalization. ${ }^{14}$ 


\section{Czechoslovakia}

Among the several countries in Eastern Europe, only Czechoslovakia had maintained a good relationship with the Westerners and the Soviet Union. They managed to establish their economy and politics and changed the social behaviour in their community. In 1946 election the observers agreed that the election was conducted lawfully and orderly. The election had provided ample seats to the Communist Party in the government when it won almost 40 percent of votes in Czechoslovakia ${ }^{15}$. Majority of the voters came from the rural area. They believed that Czechoslovakia Communist Party was backed fully by Soviet Union, the big power.

- In Czechoslovakia, a coalition government of Communist and democratic parties formed in exile in Moscow in April 1945- returned to Prague in May 1945 after the country was liberated from Nazi occupation. The Communists, who held the key ministries of the interior and information, took immediate advantage of their position to infiltrate the police and mount a massive campaign to convince the public they stood for patriotic and benevolent social reforms. At elections held in May 1946, the Communists obtained 38 per cent of the vote and 114 of the 300 seats in the constituent assembly, but attempts to achieve an absolute parliamentary majority by gaining control of the Social Democrats were unsuccessful. In January 1948, an opinion poll predicted a 10 per cent fall in the Communist vote at the elections due in Mac 1948. Realising the Communists were unlikely to gain power legally, the Communist Minister of Interior precipitated a crisis in February 1948 by dismissing eight Prague police inspectors. The majority of the cabinet members voted for their reinstatement, but was over ruled by the Communist Prime Minister and as a result 12 non-Communist members of the Government resigned. Under the threat of civil strife by worker activists in the factories, who had been mobilized and armed by the Communist Party, the President was forced to accept these resignations and to agree to the formation of a new Government in which the Communists had an absolute majority. The leaders of democratic parties were eliminated or fled abroad. The Social Democratic Party was amalgamated with the Communist Party and other parties were purged.

\section{Bulgaria, Hungary, Romania and East Germany}

In Bulgaria, Hungary, Romania and East Germany, the Communist parties participated for a time in united front coalition governments, though immediately they began the process of undermining their coalition partners. They set up bogus parties run by Communist sympathizers and suppressed or infiltrated the other coalition parties whose leaders were discredited, imprisoned (sometimes in former Nazi concentration camps) or executed. Elections eventually took place under conditions of terror and fraud. By 1949, the Communists had purged, neutralized or destroyed all genuine opposition. Elections were then held on the basis of communist-dominated single lists and the familiar pattern of huge percentages in favour of the approved lists was established. 


\section{Albania and Yugoslavia}

Developments in Albania and Yugoslavia appeared similar at first, but both later broke with the Soviet Union. In Albania, the Communists used military force to eliminate all opposition and held elections in December 1945 on the basis of a single list of Communist-sponsored candidates. In Yugoslavia the Communists, led by Tito were in a commanding position. When the fighting ended and through their control of the militia, security authorities, press and radio they were able to establish their supremacy relatively quickly and easily after the one-sided elections in November 1945. However, Tito was unwilling to accept direction from Moscow and in 1948 Yugoslavia was evicted from the Communist camp.

-

Yugoslavia's break with the Soviet Union in 1948 led to Soviet concern that other East European Communist regimes might follow his example. As a result, Stalin had a series of treason trials staged, in 1949, of Communists suspected of nationalist sentiments. Among those convicted and executed were Laszlo Rajk, Hungarian Foreign Minister, Koci Xoxe, Albanian Interior Minister and Traicho Kostov, a leading member of the the - Bulgarian Communist. These trials were accompanied by purges of party officials and members. In 1961, Albania broke with the Soviet Union after Albanian accusations of Soviet "revisionism" and allegations of a Soviet plot to overthrow the government.

Since the end of the Second World War, the Soviet Union has seen the installation of Communist governments in Eastern Europe as irreversible and that it was ready to use military force when Soviet domination through Communist regimes was threatened. In - 1953, Soviet troops put down disturbances in a number of cities in the German Democratic Republic (established in 1949) which had begun following a 10 per cent increase in work norms imposed by the authorities. In 1956, Soviet troops intervened in Hungary when the Communist leadership proposed political reforms unacceptable to the Soviet Unions in response to workers demands for better wages and political freedom. In to persuade the Communist Party under Alexander Dubcek to moderate or withdraw reforms, which the Soviet Union found objectionable. Brezhnev was reported to have told the Czechoslovak reformers: "we bought this territory at the cost of enormous sacrifices and we shall never leave it". The argument that it was the duty of Communist State to defend the gains of Socialism whenever they were threatened became known after the Soviet intervention in Czechoslovakia as the Brezhnev Doctrine.

\section{Situation at the End of the War}

In Yugoslavia, the Socialist Party had never played any important role and in the partisan struggle was absorbed into the Popular Front and virtually disappeared as a separate organisation. No serious attempt was made to revive it under the Tito regime. 
In other countries of Central and Eastern Europe, the position was different. In Poland, Hungary and Eastern Germany the Socialists had always had, and retained at the end of the war, vastly more popular influence than the communist, particularly in Poland. In addition, in Bulgaria and Czechoslovakia the socialist parties, though as it turned out, smaller than the communist parties had considerable influence, good reputations, and a long tradition of activity.

\section{Communist Tactics Since 1944}

In the struggle to consolidate, Communist power in Eastern Europe, which has been - going on since 1944, all non-Communist organizations of every sort were subjected to similar pressures and were progressively eliminated as independent forces. The Socialists had similarly suffered with one important modification, that though stooge "Socialists' were permitted a temporary puppet existence, they were all later merged in the Communist parties so that no alternatives workers party however weak and controlled, may suggest by its mere existence that an alternative and free brand of socialism exists.

- The Communists have everywhere concentrated their fury against the left wing opposition, Socialist and Peasant and it is worth remembering that in the two areas where a successful resistance had been organised against them i.e. Berlin and Finland, it was under Social-Democratic leadership. ${ }^{16}$

\section{Czechoslovakia}

\section{C}

$\infty$

In an attempt to consolidate communist power in Eastern Europe, which had been ongoing since 1944, all the communist parties were separated and put under pressure and

- progressively eliminated as 'independent forces'. The first step to enforce the control on

- the Socialist party was taken during the war. This happened when the Democrat Social

— Party of Czechoslovakia, consisting for organisational purposes, the émigré leaders in

Moscow, London and elsewhere, was manipulated by appeals to allied unity and the necessity of a pro Russian alignment and by plain intrigue and pressure to accept the leadership of the fellow traveller Fierlinger and his associates.

In another instance of communist consolidation when the Red Army penetrated Prague and the Communist took over the Ministry of Interior, the Democratic-Socialist Party were given permission to reassemble even though the party showed itself extremely restive and unwilling to be a mere Communist puppet. Further achievements were an apparent reversal of Fierlinger's policy as at its congress in December 1947, the new pro Communist party machine was able to keep control to prevent anti communist action at the time of coup de' etat of February 1948, and a few months later to dissolve the party into the Communist Party. Many prominent independent socialists fled the country while others were arrested. 


\section{The Process in Poland}

In Poland, similar action was taken under some what similar conditions. The Lublin Committee, in 1944 represented only the Communists and fellow travellers while the mass of Polish sentiment looked to the London Government, which included the prominent Socialist leaders (as was demonstrated in the Warsaw rising of that year). Fellow travellers, headed by Cyrankiewicz, were allotted by Moscow the leadership of the Socialist Party. When the Lublin Committee declared itself, the Provisional Government of Poland this group was given the task of organising a Socialist Party. The real Socialist Party remained loyal to its leaders in exile, and no compromise was permitted by the Russians even when Mikolajezyk returned to Poland and the Peasant Party was, for a long time allowed to organize independently ${ }^{17}$.

With no apparent alternative many Socialist workers in Poland joined the new Cyranklewicz Party in the hope that it could be made into a real Socialist party to resist Sovietization. However, by judicious purging Cyrankiewicz was able to control the machine to dismiss disgruntled colleagues and to set the party a program of unifying - itself with the Communists. These steps were highly unpopular with the rank and file. At the party Congress in 1947, they were able to prevent its immediate realization but this was merely a postponement. In 1948, after a further purge, the merger took place willynilly. The organization of the old genuine Socialist Party continued underground as in the Nazi times and veteran Puzak, who had been in Tsarist jails again went to a Russian control prison for this activity.

\section{Tactics in Bulgaria and Romania}

In Bulgaria and Romania, rather different tactics were pursued. No émigré groups

existed; but the Socialist Parties had maintained rudimentary illegal organizations in the n countries themselves, with which the Communists collaborated to overthrow the proGerman regimes. In the period of initial collaboration, both before and after the expulsion of the Germans, the Communists infiltrated as many sympathizers as possible into Socialist leadership and obtained the exclusion, in the name of unity, of some of the more active anti-Communists.

At an early stage in Romania and Bulgaria, attempts were made to take over the Socialists by unconstitutional or packed Party congresses. These tactics were a partial failure, for although the party funds, premises and newspapers were seized by the communist police and handed over to, the still in force, recognized leaders Petrescu and Cheshmedzhiev (and after his death Lulchev) were able openly to oppose the fake and to obtain with great difficulty, temporary facilities for reorganization without funds, files premises or anything except the support of the Party masses (e.g. the Bulgarian free Social-Democratic paper 'Svoboden Narod' obtained over ten times the circulation of its official rival Narod). The next stage was the destruction of the Socialist opposition by the 
suppression of its newspapers and the arrest of its leaders - the Bulgarians Socialist leaders became the victims of faked treason trials, while Petreseu was imprisoned without trial for over a year. The pro Government rump 'Socialist Parties' were then absorbed into the Communist Party. ${ }^{18}$

\section{Absorption and Elimination in Hungary}

In Hungary, warned by the temporary failure of the shock tactics in Bulgaria and Romania, the Communists went rather slower, secured the gradual expulsion of moderate Socialists, faked the 1947 elections to reduce Socialist influence and hence independence - and finally reduced the party, under the imposed leadership of the contemptible Szakasits to a state where it could be absorbed. The communist took control of the Ministry of the Interior, State Secretary's Office and the secret police. The party demanded the leadership and tolerated no respect of coalition proportion. ${ }^{19}$ The moderate leaders, Ban and Payer escaped to the West.

\section{The Soviet Zone of Germany}

In Eastern Germany, the matter was simpler. Under Soviet military orders, a faked Congress proclaimed a merger into the Communist Party in the form of a 'Socialist Unity Party'. The fact that support for such unity from Social Democrats was negligible was demonstrated in Western Berlin where the S.E.D was a total failure. However, this simple - act of force strongest and most popular party and the taking over of its fund and premises by the Communist Party. Soviet control over East Germany had introduced fear towards the Russian-Germany pact and provided the opportunity to the Soviet Diplomat there. ${ }^{20}$.

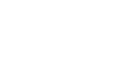

- Besides that, like the other countries in Eastern Europe, freedom of the newspaper was n blocked and numerous reporters jailed. The Soviets had prohibited any type of communication with the West. All institutions came under the Soviet control except the churches whose assets were seized. Churches came under the control of the government and priests were imprisoned. In East Germany, itself, one third of its population had left the country in $1953^{21}$. In all Eastern Europe, the true Socialist leaders were eliminated by pressure, intrigue, or sheer police action; independent Socialist Parties were suppressed and the puppet parties were then merged into the Communist Party.

\section{Conclusion}

The success of the Soviets to implement the communist ideology in Eastern Europe was influenced by several factors. This discussion has shown that, Soviet Union status as a super power in Eastern Europe had served as an advantage and provided the confidence to all the Eastern Europe that the Soviet is one and the only power that can defend and protect their welfare. For the other states in Eastern Europe, that had created problems to 
the Soviet, they implemented salami tactics in order to make sure that the creation of communist states were a success. Even though, salami tactics were thought as a Soviet strategy in order to make sure the creation of Communist States in Eastern Europe, it must be remembered that without the support of the people, these tactics would not have been successful. Being a super power in Eastern Europe had given the Soviets great advantage to strengthen her position in Eastern Europe after the World War II. Yalta Conference which gave sphere of interest to Soviet in Eastern Europe made it easier for Soviet to strengthen her position over these territories.

\section{Endnotes}

(1)

${ }^{1}$ Joyce and Gabriel Kolko, The Limits of Power, Harper\&Row. New York. Pg 31. 1972.

${ }^{2}$ See FO 973/404

${ }^{3}$ FO 371/ 85748 'Note on Post-War negotiations on Spheres of Influence', 13 March 1950.

${ }^{4}$ See FO 973/404

${ }^{5}$ See FO 973/404

${ }^{6}$ Salami tactics, also known as the salami-slice strategy, is a divide and conquer process of threats and alliances used to overcome opposition. With it, an aggressor can influence and eventually - dominate a landscape, typically political, piece by piece. In this fashion, the "salami" is taken in slices, until one realizes (too late) that it's gone in its entirety. In some cases it includes the creation of several factions within the opposing political party and then dismantling that party from the inside, without causing the "sliced" sides to protest. www://en.wikipedia.org./wiki/salami_tactics.

${ }^{7}$ According to Marxism-Leninism just wars are those waged to protect the interests of the working class and the toiling masses, to liquidate social and national oppression, and to protect national sovereignty against imperialist aggression. The most just wars are those waged in defense of the socialist fatherland. In contrast, unjust wars are reactionary or predatory wars waged by imperialist countries.

${ }^{8}$ ibid

${ }^{9}$ FO $973 / 404$

10

11 Stephen Fischer -Galati (editor), The Communist Parties of Eastern Europe . Columbia University Press. pg. 245-246. 1979. 
${ }^{12}$ Ibid pg. 245.

${ }^{13}$ Stephen E. Ambrose, Rise to Globalism. Penguin Books USA. pg 139. 1973.

${ }^{14}$ http://www.time.com Monday, April 14, 1952, Hungary : Salami Tactics

${ }^{15}$ Seton Watson. H. Nationalism and Communism Essay 1946-1963. Methuen And Co. Ltd. 1964. pg 119.

16 FO 975/45

${ }^{17}$ ibid

- 18 ibid

19 http://www.time.com Monday, April 14, 1952, Hungary : Salami Tactics

${ }^{20}$ Robert F. Byrnes, Russia In Eastern Europe : Hegemony Without Security. Foreign Affairs. Vol. 49. Nos 1-4, October 1970-July 1971, New York. USA. pg 682.

- ${ }^{21}$ Charlotte Waterlow and Archibald Evans. Europe 1945 to 1970. Methuen Educational Ltd. London. 1973 pg. 147.

\section{References:}

FO 973/404 - Origins of Communist Rule in Eastern Europe.

FO 975/45- A Communist Technique Examined.

FO $371 / 85748$

Charlotte Waterlow and Archibald Evans. 1973. Europe 1945 to 1970. Methuen Educational Ltd.

George F. Kennan. 1970. American Diplomacy 1900-1950. Chicago: The University Of Chicago Press.

John C.Campbell . 1965. American Policy Toward Communist Eastern Europe : The Choice Ahead. The University of Minnesota Press. USA

John Lewis Gaddis.2005. Strategies of Containment. Oxford University Press. USA.

Joyce and Gabriel Kolko.1972. The Limits of Power, Harper\&Row.New York. 
Robert F. Byrnes, Russia In Eastern Europe : Hegemony Without Security. Foreign Affairs. Vol. 49. Nos 1-4, October 1970 - July 1971, New York. USA.

Roy Macridis. 1952. Stalinsm and the Meaning of Titoism. World Politics. Vol. 4, No. 2 (Jan).

Seton Watson. H. 1964. Nationalism and Communism Essay 1946-1963. Methuen And Co. Ltd. USA.

Stephen E. Ambrose.1973. Rise to Globalism. Penguin Books. USA.

- Stephen Fischer -Galati (editor), 1979. The Communist Parties of Eastern Europe . Columbia University Press. USA.

http://www.time.com Monday, April 14, 1952. Hungary : Salami Tactics. 